\title{
Autumn Lecture 2018, presented by Baron Myners of Truro: in investment how do we define long term? Abstract of the Edinburgh Discussion
}

[Institute and Faculty of Actuaries, Sessional Research Event, Edinburgh, 7 November 2018]

The President (Mr J. Constantinou, F.F.A.): It is my pleasure to welcome you to the 2018 Autumn Lecture here in Edinburgh.

I am delighted to introduce our speaker for this evening, Lord Myners. In his lecture he will share his thoughts on how we define long term when it comes to investment.

Long-termism is a subject close to actuaries' hearts. Lord Myners is particularly well-placed to speak on the subject. He is Chair of the UK operations of Cevian Capital LLP, where he is responsible for identifying potential investment targets, working with boards and building alliances with other investors.

From 2008 to 2010 Lord Myners served as Financial Services Secretary in Her Majesty's Treasury. Prior to this, he had an active career in the City of London with NM Rothschild. Before entering government, he also served on the boards of a wide variety of organisations, including as chairman and director of Guardian Media Group, chair of the Low Pay Commission and chairman of Marks \& Spencer Group.

He has also served as a non-executive director of the Bank of New York, since 2002, and the Bank of England from 2005 to 2008.

Some actuaries may recall the 2001 Myners Report, a review of institutional investment for Her Majesty's Treasury, the recommendations of which made a valuable contribution to collective investment and, in particular, pensions investment.

Lord Myners of Truro: In late June 1988, I was invited to the Bank of England for afternoon tea by Jonathan Charkham. Jonathan was a former industrialist, barrister, Chair of the Athenaeum Club, father of the leading divorce lawyer Fiona Shackleton and advisor to the Governor on business. The Governor at the time was Robin Leigh-Pemberton, a Kent landowner (whose estate included the only private Eton Fives court in the country). He had no financial qualification or executive experience in banking: he was probably second only to Eddie George as the most successful Governor in the post-war period. Tea was served from a silver pot with best Staffordshire china.

Jonathan wanted to talk about his growing concerns about the short-term focus of public equity investment. Jonathan's interest led him to push for the Cadbury Code and he actively promoted ProNed, a bank initiative to improve the quantity and quality of independent directors.

We both rejected the definition of short-termism as the elapsed period of a share holding by an individual investor, a subject which the Investment Management Association and London Business School were later to offer, misleadingly in my view, as a proxy for short-termism, with the conclusion that it was not a problem. Since then the velocity of individual shares trades has increased astronomically.

Jonathan and I were both focused on investor attitudes. We saw an increasing focus on securing an early return from an individual equity investment (aggregated within a diversified 
portfolio) at the expense of looking to the distant future - investment that was more farsighted and enduring.

I had become Chief Executive of Gartmore Investment Management in August 1985. Gartmore was a small independent house, with a joint heritage in Glasgow and London. It managed little more than $£ 1$ billion.

Each day I received on my desk a computer printout indicating the percentage shareholding we held for our clients in every company in which we had invested.

Initially, this report showed many low numbers - $0.1 \%, 0.4 \%$, etc. - consistent with our modest scale.

But as we grew our funds under management, these percentages increased, and I began to see the occasional $5 \%$ and then $10 \%$. (Gartmore ultimately grew to over $£ 80$ billion under management by 2001.)

At one of our weekly equity investment meetings, I asked my colleagues whether they believed that there was a point at which our percentage ownership of a company might mean that we have moved into a position of having new responsibilities - responsibilities to a firm as a leading owner. I posited that our responsibilities at a $0.1 \%$ level of ownership were generic, but asked if the same applied at, say, $10 \%$. My colleagues rejected my view. They argued that because we owned $10 \%$ at a particular moment, it did not necessarily imply a different view or commitment. Our clients had placed their money with us to achieve better returns than they expected to get from other managers and the return from indices. Accordingly, we managed diversified portfolios to beat benchmarks and indices and delivered generally satisfactory returns to our clients. We did not see ourselves as owners.

Gartmore, and other similar investment managers, placed a premium on portfolio liquidity the ability to sell an investment fairly quickly - and did not want to become "insiders" and we certainly had no real competency to engage as owners. Nor did we believe our clients expected us to do this - not least of all because they never raised the subject.

In the terms used by the German political economist Albert Otto Hirschman, we preferred "Exit" over "Voice". Hirschman, whose work had a profound impact on competition policy, saw two primary options when customers, voters or members saw a deterioration in an organisation. They either Exit, withdrawing from the relationship (an economic act), or Voice, attempting to improve the relationship and outcomes (a political act). Institutional investors in UK quoted equities have shown a consistent preference for Exit. This is a direct consequence of setting relative investment performance goals, monitoring performance against benchmarks and indices and using time measurement periods set by clients, periods that were mostly misaligned with the ultimate purpose of the sponsoring fund.

The necessarily high portfolio diversification led to many portfolio managers owning investments in hundreds of individual companies. And here I am referring to self-acclaimed active managers. I will come to index, or passive, managers, in a moment.

Portfolios began to look increasingly similar, according to a leading consultant, as managers largely mirrored benchmarks with only occasional significant deviations in the hope of securing the modest out-performance against the benchmark set by clients.

Any idea of such fund managers being engaged owners was a nonsense. The fund managers had neither the economic incentive or skill to become surrogate owners. They valued the freedom to trade over the ability to engage.

Fund management firms have tried to address this - and the public policy risks of not being seen as engaged owners - by the appointment of "governance experts". These people tend to be wellintentioned but frequently under-resourced and under-recognised in their own firms. They are not, in most cases, truly integrated in portfolio construction. They rarely have relevant experience at senior levels in real businesses in a way that would equip them to engage constructively, and in detail, with companies on strategy, culture, capital allocation and purpose. Their agenda is largely focused on the mechanics of voting and executive renumeration - and they have not always done a great job on the latter. 
The conventional view at the time of my meeting with Jonathan - and remember this was the era of Hanson and BTR - was that takeovers were the most effective way of clearing up corporate detritus. Not much has changed. The UK still has the most permissive approach to takeovers in the developed world. At a $30 \%$ premium to the current market price, nearly every UK company is open to a successful corporate offer. This is one of the principal reasons we no longer have any pure technology companies in our main index. They have been sold.

I will focus on publicly quoted equities. I will make occasional references to academic work. I will be the first to volunteer that much of the work in this area is not definitive as academics have to make subjective judgements about the short term and the long term and how they measure them. But the evidence I cite accords with my own experience of over 40 years - including as a fund manager and board member.

It is my central contention that business leaders are prone to place too much emphasis on the short term and not enough on the long term when making decisions, particularly around capital allocation, $\mathrm{R} \& \mathrm{D}$ and innovation. I believe that this is in significant part due to pressure from institutional investors (fiduciary owners), themselves reflecting the short-term focus of their clients, the asset owners.

A report published by the Aspen Institute in 2009 concluded, "fund managers with a primary focus on short-term trading gains have little reason to care about long-term corporate performance or externalities". The simile I use to illustrate this is the tendency to drive and maintain a rental car with less care than the car we own.

The short-term focus I have been describing reduces aggregate investment returns and detracts from economic prosperity and social welfare. There is a real cost. We need to get to grips with the causes of this perverse bias to the short term.

No one runs a marathon based on being better than the average runner for each individual halfmile section, but that is how many investment portfolios are expected to be managed. It is not altogether surprising that fund managers apply considerable pressure on the boards of public companies to produce short-term returns, and that the half-life of company CEOs continues to decline. Asset owners, pension trustees and others have set up investment managers to achieve impossible goals - consistent sustainable out-performance against peers and indices over irrelevantly short-time horizons. Relationships can, accordingly, be fractious between asset owners and managers and the lifetime of many investment mandates can be short (notwithstanding the evidence suggesting that pension fund trustees, whose thinking tends to be heavily influenced by price momentum, show little skill in shifting a like-for-like equity mandate from a "losing manager" to a "winning manager").

Where is the evidence of this short-termism in business investment? In early 2013 McKinsey and the hugely respected Canada Pension Plan Investment Board conducted a survey of more than one thousand members of public company boards around the world:

- $63 \%$ said the pressure to generate strong short-term results had increased over the previous 5 years.

- $44 \%$ said they had a time horizon of less than 3 years in setting strategy.

- $73 \%$ said they should use a time horizon of more than 3 years.

A survey by Focusing Capital on the Long Term (FCLT) suggests that $61 \%$ of executive directors would cut discretionary spending to avoid earnings miss and $47 \%$ would delay starting an important new project to manage a similar situation.

Graham and Harvey, at Duke University (2006), found that $39 \%$ of the public company CFOs they surveyed would financially induce customers to bring forward purchases and take other similar cosmetic actions to meet short-term earnings targets. Wall Street lawyer, Marty Lipton, observes that companies and their boards are "caught in a quarterly trap" - the long term is for the birds.

A tendency to myopia is also evident from the sell side, with few researchers producing detailed forecasts more than 2 years out (and none, as far as I am aware, beyond 5 years). 
The frustration experienced by public company directors is evidenced by a report produced in 2008 by Acharya, Kehoe and Reyner who interviewed directors who had sat on boards of both public and private companies. Their limited sample showed a strong bias in favour of membership of private company boards (including private equity) where they thought there was more focus on value creation and less bias to risk avoidance. The latter is manifestation of "no surprises" expectation of public companies. The depths to which "no surprises" is embedded in public equity behaviours is, perhaps, evidenced by the fact that we tend to say that companies have missed analyst forecasts rather than that the analysts simply got their forecasts wrong; that is, we point to the company as the failure in this form of narrative.

The Bank of England (in May 2011) said that a focus on the short term in business decisionmaking is evidenced in public company valuations discounting cash flows 5 years ahead at rates more appropriate for 8 years, for 10 years at rates more appropriate to 16 years and applying scarcely any value to cash flows beyond 20 years.

This follows on from work by David Miles (1993) who concluded that "the discount rate to value companies and evaluate projects appears to be consistently higher than can be explained by fundamentals".

This is powerful evidence that accords with my experience of sitting on the boards of more than 20 public companies. Discount rates were nearly always too high, and far too much emphasis was placed on supporting projects with significant early year paybacks. This is not a climate that encourages investment in new ventures with risk. It points business management to focus on in-fill investments, cost reduction, dividends and share buy-backs at the expense of investment and innovation.

I know that some might query how this observation about discount rates stands alongside what appears to be high valuations of current cash flow in sectors such as technology and health, but you will find that these largely correlate with an expected surge in cash flow over the foreseeable future.

The consequences of a short-term focus in business investment are high. Economists have estimated that use of inappropriate discount rates may have had a negative impact on annual UK GDP of the order of $0.1 \%-0.3 \%$ - not an insignificant number in the context of projected economic growth rates, and certainly a credible contributor to the national productivity challenge. We are talking here of a wasted asset - an alchemy that has turned gold into lead.

Nothing I have said so far is particularly new. A 2004 Mori Survey for the Investment Management Association (IMA) and National Association of Pension Funds (NAPF) asked if investment mandates created short-termism in business and investment management. A third of the NAPF (NAPF) members and two thirds of the IMA members agreed. This view was echoed by the report from a focused Chartered Financial Analyst Symposium in 2006.

Until we address this question, we will continue to see fund managers holding "under-weight" positions (against benchmark) to manage tracking error down to a level which does not make economic sense. The widely used practice in equity portfolio construction of under-weighting is the holding of shares that the fund manager expects to produce sub-market returns but where these companies represent a meaningful proportion of the benchmark. So, for instance, a manager might invest $2.5 \%$ of a portfolio in a share which he or she believes to be overvalued because it constitutes $5 \%$ of the benchmark and the manager does not want his or her performance to suffer too much if wrong. This is at complete odds with an owner's wish to see action taken to promote profitable and value-creating corporate purpose. Why would any under-weight investor want to encourage a company to improve itself? This is not a marginal issue. I would estimate that a fifth of all UK companies' equity is held by under-weight investors who have no incentive to act as engaged owners.

We will also continue to see highly diversified portfolios accompanied by high and increasing portfolio turnover. Stock trading is expensive. Transaction costs can be a serious drag on performance, but they are incurred in the pursuit of pops in short-term performance. Not only do we 
know that most managers of public equity portfolios under-perform indices and passively managed portfolios, we also know that most pure equity portfolios under active management produce a worse outcome over more than 3 years than would have been returned had the manager simply kept his or her opening portfolio. This is little short of shocking. Imagine any other profession - medicine or engineering - that would use a proof statement that asserts that you would probably enjoy a better outcome if you did not use its practitioners.

Also, fund managers will over-promise and under-deliver whilst earning fees for adding little value over the market. Most fund managers have a better time-weighted rate of return than money-weighted, reflecting a tendency for clients to direct money to managers with recent good performance (generally five years or less) and away from managers with recent poor performance who might be about to benefit from some form of mean reversion. This is another aspect of pervasive short-termism.

I cite as further evidence of our short-term bias the fact that we are comfortable to describe corporate management incentive schemes as long term if they apply to performance measurement periods of 3 years, analysis of corporate earnings calls that show that investors focus on the very near term, and the relatively small number of public companies emboldened to speak meaningfully about 10 -year visions or similar.

I am afraid that much of this is a pain for the investment management industry. Like my colleagues at Gartmore 30 years ago, they would rather not have the responsibilities. Large shareholdings are simply an unwelcome consequence of commercial success in asset gathering to lift the management firm's revenues, bonuses and profits. I suggest, somewhat provocatively, that the relative detachment of the fund management industry from shaping public policy on the economy and regulation is evidence of the industry's discomfort.

An efficient capital market transfers the savings of today into the investment for tomorrow and growth the day after, boosting welfare. Short-termism of the type I describe is short-changing fund beneficiaries and society.

So, what can be done? I have rejected ideas such as giving investors who own shares for longer periods more votes or a dividend lift because this does not address the fundamental issue of attitude.

There are things that the Government and regulators could do. The Treasury and its agencies have taken some positive initiatives, including pushing hard for the adoption for Markets in Financial Instruments Directive II (MiFID II), albeit 17 years after I first pointed out the absence of transparency and perverse economic incentives arising from the way sell-side analysts were paid.

The Treasury also responded positively to issues raised by Sir Damon Buffini in his Review of Patient Capital in 2017 and through the adoption of several its conclusions and the launch of British Patient Capital to enable long-term investment in innovative companies across the UK. The required frequency of financial reporting by public companies has also been helpfully reduced.

Government's hand is also clear in pushing the Financial Reporting Council to add more bite to the Stewardship Code and in encouraging investors to continue to support the Investor Forum, established after the Kay Review.

There are other areas where the Government can work in the interests of promoting a move to higher portfolio conviction - reflected in fewer individual investments and the curtailing of underweighting. The Treasury should consider the case for introducing capital gains tax as a charge within investment funds rather than a payment to be made on disposal of the investment in the fund. This practice has been adopted in many other jurisdictions, including the United States. It deters trading within the fund and puts private investors on the same footing as those who invest through funds. Pension funds and other tax-exempt funds could also be made liable to capital gains tax, with an adjusting credit to tax on income in order to be fiscally neutral. These changes would have the side benefit of accelerating receipt of tax by the Government. It is a 
testimony to the lobbying power of the financial industry that the Treasury has not made this change.

Or the rate at which Securities Stamp Duty is charged on equity trades should be increased and extended - pound for pound - to equity derivatives - a form of enhanced Tobin Tax.

The Financial Conduct Authority (FCA) should continue its "Truth in labelling" project to flush out closet indexers with very low active components in portfolios but charging the higher fees associated with active management.

The FCA also needs to turn its attention to the question of liquidity restrictions on redemptions from funds, particularly those funds targeting retail investors. It isn't sensible to propose to investors that equity investment can be made with the same access to liquidity as withdrawing cash from an ATM. The offer of immediate cash on fund redemption obliges portfolio managers to create highly diversified portfolios with multiple liquid holdings in order to meet potential fund sales. This can frustrate any wish they might have to show greater conviction in stock selection. Equity investments are subject to fluctuations in the liquidity of the stock market. This should be reflected in fund terms. I suggest that no equity fund should be redeemable on less than 7 days' notice and more specialist funds should require notice periods of, say, 30 days. If an investor finds such restrictions unacceptable, it is almost certainly true that equity investment is not for them, at least at this time.

In 2001 I produced a Review of Institutional Investment for the Treasury. The Review ran to a couple of hundred pages, but the key message can be captured in a single sentence: There needs to be a step change in the competency and the quality of decision-making by asset owners (pension trustees, etc.).

Asset owners are the source from which the great river of investment emerges. They determine risk appetite and asset class allocation. They set guidelines for portfolio managers, including those with a public equity mandate, and determine performance review processes. It is difficult to imagine that significant change in "the investment chain" is going to happen without a lead from asset owners.

In the Review, I proposed a set of Investment Principles to improve the overall effectiveness of institutional investment. These Principles were then subject to further review by the Government before promulgation under a "comply or explain" protocol. They were reviewed again by the NAPF in 2007 and then incorporated, with only minor modifications, into the Investment Guidance Manual published by the Pensions Regulator last year.

I am pleased to say that there has been a noticeable improvement in the standards of investment trusteeships since 2001, particularly by larger pension funds that can afford more comprehensive governance oversight.

That said, we need greater ambition to further raise the standards of professionalism, competency and accountability of scheme asset owners. We have not travelled as far as I had hoped in this and many other aspects of matters covered in the Investment Principles.

As I have suggested earlier, asset owners continue to follow strategies and practices in public equity portfolio management that are poorly informed and likely to lead to sub-optimal outcomes.

I suggest they fail to recognise the opportunity, indeed imperative need, to follow through from simply investing in shares to ensuring that they, or their managers, take a more engaged role as effective owners. I don't believe that this can be achieved without at least some UK equity managers appointed by asset owners being granted more freedom in portfolio construction and longer performance measurement time horizons. This is consistent with Investment Principle 7, which proposed greater flexibility around investment objectives and risk parameters if trustees were confident in their portfolio manager's capacity to achieve higher returns.

I also recommended in 2001 that investment trustees should measure and report on the effectiveness of their own decision-making. Few have managed to do this in a way that inspires confidence. Most produce little more than boiler plate statements. They do not explain their core beliefs and how these are carried through in their fund. Few provide useful data on the success or not of their decisions. This needs to be rectified. 
The time has come for a thorough review of the Investment Principles with a challenge to raise standards in general but, in particular, to ask questions about issues relating to short-term forces and with provisions to direct participants to address and account for their behaviours. There have been enough incidents of poor trusteeship and investment governance oversight over the last 10 years to justify a review. And the Treasury should certainly be interested in raising the issue of short-termism as an opportunity to change practices and potentially benefit national output.

I urge the Department for Business, Energy and Industrial Strategy, the Department for Work and Pensions, the Treasury and the Pension Regulator to give consideration to mandating a new review which would bring a fresh pair of eyes to challenging current practices in the area of governance of funds, the attitudes of fund managers to governance (the Stewardship Code barely scratches the surface) and the potential improvement to national economic performance.

In trying to bring this together, what sort of change in the management of public equity am I proposing?

I look at the investment determinations of asset owners in the way one might look at public horticultural allotments. There is plenty of room to grow many different types of fruit and vegetables and to permit many different approaches to planting, protecting and growing. But our investment allotment is missing the opportunity to sponsor a new form of public equity investment that focuses on the longer term and seeks to nurture and strengthen underlying portfolio companies rather than simply trading their shares.

I believe this can be done. I am a general partner in a $€ 13$ billion fund focused on equities in Northwestern Europe. We have a concentrated portfolio with a target of only 10-12 holdings. We generally make only one or two portfolio changes per annum. We are normally the largest or second largest shareholder in our portfolio companies and we currently sit on circa $75 \%$ of the boards of our investee companies. We pay no regard to index construction. We have no under-weight holdings. We take an intensive interest in our portfolio companies both at the time of investment and during our ownership. We generally have at least two professionals within the firm who spend most of their time focused on a single portfolio company. We have something of the order of 150 meetings before we make an investment - covering competitors, suppliers, customers, regulators, trade unions, etc. We particularly make a point in meeting with the company's independent directors, something which mainstream investors only do around remuneration matters or when a crisis has occurred. We are also enthusiastic supporters of shareholder participation on nomination committees, as practised in several Scandinavian markets.

The nominations committee is in many ways more important than the committees overseeing audit or remunerations as it controls the process by which candidates become members of the board and its committees. But this committee has received little attention from those who write on governance - certainly much less than audit and remuneration. There is a particularly strong case for the UK to, at a minimum, adopt the practice of placing appropriately experienced people from major shareholders on the nominations committee when a company comes to select a new chair. I would hope, in considering this and other ways in which the standards are set, for nominations committees to draw openly on the experience of practice in other jurisdictions. I hope the Financial Reporting Council will commission such a review.

I am not suggesting that this is a model which is appropriate for all funds or should be broadly replicated. I see more opportunity for fund managers who can justify being given more freedom to construct public equity portfolios with much more concentration and conviction than is currently the standard. I am projecting a model, which might be described as a hybrid that brings together the best of public and private equity approaches, to produce superior returns and better ownership, including an aligned focus on the longer term.

To be successful, this approach needs a radically different mindset from the fund manager with an inclination to Voice rather than Exit. A willingness to be "insiders" for extended periods if this facilitates effective Voice. The skill set required from such portfolio managers is going to include serious experience in corporate management and leadership. It is rare that you find such people on 
the staff or in the governance units of mainstream equity managers - the insights provided are not relevant to running portfolios with low stock-specific risk and highish levels of trading.

In closing, I will cover a few points in brief.

Over the last 10 years, passive fund managers have increased their ownership of total US equities from $15 \%$ to $35 \%$, while the figure for Europe has increased from $14 \%$ to $26 \%$ (source: Investment Company Institute and Broadridge Global Market Intelligence), and this excludes a further tranche of equity managers with a low active element in their portfolios.

How much further can this go before markets become seriously less effective in pricing risk and allocating capital? I would suggest, as a minimum, that the growth of passive management - itself a strong statement by asset owners about their assessment of established approaches to active equity management - requires the counterbalance of other managers who take a longer-term view and are more engaged in the role of company ownership.

One of the reasons we have seen the growth of "unicorns" (substantial companies that remain private whilst having significant institutional ownership) and the decline in quality of IPOs in the UK over recent years is the increasing frustration of entrepreneurs with the thinking and inconsistent attitudes of public equity investors. Many of our best innovators and the next generation of business talent are simply concluding that running a publicly quoted company is not for them.

I am not saying that a much shorter-term approach might be appropriate for other asset classes. Credit springs to mind.

I am setting out an agenda for a fresh look at the causes and consequences of short-termist attitudes and behaviours in the investment chain with specific proposals around investment principles, corporate governance, taxation and regulations. I am also putting forward for consideration a new form of public equity management, a hybrid between private equity and public equity management that places more focus on constructive share owner engagement with commercial companies and their boards.

The views I express are my own. They do not necessarily reflect the views of any organisation with which I have a relationship.

The President: Lord Myners started off with the asset managers, then went into the business leaders and from there looked at the trustees and eventually ended up with unicorns!

There are actuaries who are thinking, "I am sure he is wrong. We should be having a broad enough portfolio to diversify".

Let us start with the questions.

Mr J. A. S. Stevenson: I am a Member of the Scottish Parliament. Is the conclusion that we should reach from the proposition that we have just heard, most of which I find myself in agreement with, that we should require investors to sit an exam to show that they understand the business in which they are investing before they are allowed to invest? Or is that too extreme a conclusion?

Lord Myners: When I did my review in 2001, I was originally minded to setting a test of competency before somebody could become a trustee of a fund. We did some tests on investment understanding among trustees. I remember that one of the questions that we asked 400 or so trustees was: "If long-term interest rates rise, does the price of a fixed income security increase or fall?" We did not consider convexity and other things.

The problem with this question was that there is a 50-50 chance that you get it right. So, there was a supplementary question which said: "Are you confident that you got the answer right?"

Thirty-four per cent either got it wrong or were right but were not confident. If you have not understood the relationship between interest rates and bond values, you have not gone very far in investment knowledge. So, I wanted to have a competency test until Sir John Kingman, who is now Chairman of Legal and General and doing a review on the Financial Reporting Council, but who 
was then a Treasury official, pointed out to me that if we introduced this test of competency, most members of the Cabinet would not be able to serve in their present positions.

As part of a self-evaluation process, if I were a trustee, I would want to satisfy myself that my colleagues around the table were familiar with these issues and that they were spending time reading and keeping up-to-date on issues and were open to new suggestions.

The President: Let us take the first question on Twitter. It is from the immediate past president Marjorie Ngwenya asks: "What do you think about long-termism in investment in emerging markets?"

Lord Myners: We need to ask ourselves far deeper questions about indexation or the indices that we replicate.

When I first went into fund management in the mid-1970s, we had a standard line at Rothschilds that equities, and UK equities in particular, were the natural asset for a UK pension fund to hold because they balanced the nature of the asset and the nature of the liability and the currency. That is certainly not the case now. We have far more international companies. That is simplistic thinking. I am not sure whether a FTSE 200 or 500 Index is a good proxy for UK investment in any case.

When you come to emerging markets, you have additional problems around things like the quality of corporate reporting and, in particular, that in those markets there tend to be substantial related or cross-corporate holdings.

The case for active investment is even greater in emerging markets. If you follow an index, you are almost certainly following something that is deeply flawed.

The President: Another question?

Miss K. Ross, F.F.A.: I am from Royal London. Last week a task force was announced to look at the rules that apply to investment in so-called "patient capital" where investors are rewarded for investing for the long term. How far do you think that will go to help the long-term view of fund managers and trusts in the fund management industry?

Lord Myners: The fund management industry has shown itself perfectly capable of looking after its own interests, particularly in terms of the fees that it has been able to charge and the generally prosperous lifestyles of people in that industry. So, setting that to one side, it is not one of my objectives.

I do think a more patient approach to investment is necessary. I was talking to a couple of members of the Institute before, and one of them was saying they had been at a trustee meeting today. It is quite intriguing that some trustees meet with their investment managers every 90 days when funding liabilities which may not mature until 2050-2060.

The quarterly meeting is another contributor to the short-term approach. My heart used to sink when you had three bad quarters in a row and you were going to sit in front of people who were going to ask you why you were $0.2 \%$ behind the benchmark, for which the right answer was "It really does not matter; it is noise. It is happenchance that that has happened over 3 months." It is no evidence of skill at all, so why are we even reporting on performance over 90 days?

I would certainly have a 90-day check on compliance with guidelines that had been set. But the idea of having four fund managers coming in for an hour at a time in the morning to talk about the consequence of the American mid-term elections for investment in Japanese small companies. I am afraid that I spent a lot of my life doing that and I look back and think "What was happening there?"

Back to your question anything that accepts that patience is frequently a prerequisite of good performance, of riding out dips with the prospect of getting a superior longer-term return, must be 
good, and I encourage government, regulators, trustees and everybody to think longer-term and stop being obsessed with immediate gratification.

The President: I have a question from Martin White: "What do you think of the argument that active management is needed to ensure that you have price discovery?"

Lord Myners: I am not suggesting that you do not need active management, if that means valuebased investment decision-making. What I am arguing against is hyperactive, hyper shortterm focus.

Passive investment, or the index fund, replicates the index and does nothing else. It does not deviate at all.

Over the past 10 years, the percentage of American company equities owned by passive funds has increased from $15 \%$ to $34 \%$. In Europe the figure has increased from $11 \%$ to $23 \%$. Moody's forecast that most of the equity of American and European companies will be owned by passive funds - computers - by sometime between 2022 and 2027.

Martin, you are right to ask where price discovery comes from because that is important to allocate capital. We should provide capital to companies which are showing a capacity to invest it more productively than others, and the index cannot make those calls. But neither can managers who are not far away from indexation, which is why I make my case for having more managers who are more focused in their investment. They exhibit more conviction about their selection and they use Voice and other forms of support to enhance the performance of their investment. In that situation we would continue to have good capital allocation pricing.

Mr D. Bryant: I am from Standard Life. You have spent a long time talking about trustees and their effects on fund management decisions, but, with the rise of DC, increasingly individuals are investing in funds. They are unlikely to accept the volatility of having, say, 20 equities. How do we ensure a long-term view in the man in the street?

Lord Myners: There is a risk, particularly if you leave investment decisions in the hands of individuals, of reckless conservatism. Individuals will, because they are nervous about volatility, not stray very far from deposit funds and short-term debt funds.

We know that more volatile asset classes, like equities, will be priced to produce superior longterm returns. There is a risk, if left to themselves, the individuals will make not very sensible decisions.

When I was chairman of the body which became National Employment Savings Trust (NEST), the auto-enrolment investment body, we spent a lot of time using the insights of psychologists and sociologists to think about what investment options we should give. We wanted to keep it relatively short with a focus on mixed funds.

If I had had more time I would have ranted on also about the fact that funds have no voice of the investor. Very substantial investment funds are looked after by the investment management company or the insurance company. There is no equivalent of the non-executive director. I should quite like to see that happen as well.

Prof D. A. MacKenzie, Hon. F.I.A.: Listening to the discussion, I wondered if actuaries have a problem, which I would think of as a public goods problem in the technical sense of the word, because there is no doubt that active management is a public good. There are wider benefits in terms of price discovery, as a previous questioner put it, and in terms of the governance issues that you have described.

But if the efficient market hypothesis for financial economics is correct, and the evidence for it in this domain is not too bad, then the active managers that you are describing are not going to 
perform much better than asset managers, so the private benefit will not be captured. That is precisely what makes something a public goods problem.

We know that the tendency of a capitalist economy is the undersupply of public goods. Perhaps we are dealing here with a problem of that deep and often intractable kind.

Lord Myners: You have captured the issue eloquently. The unchallengeable reality is that highly paid fund managers, who sit in the front of screens and visit companies and spend lots of time with research specialists, on average, over any reasonable time period, whether they are managing endowments, pension funds or mutual funds, under-perform a randomly selected portfolio certainly the index.

I imagine if you had a model which allowed you to throw enough darts at the back page of the Financial Times you would also say a portfolio randomly selected by the throwing of darts. That is an issue, particularly if you are paying high fees.

So, fund management falls short in my view, as currently conducted, and I feel sorry for fund managers because they are just being given overly restrictive mandates and not being able to demonstrate their talent. They do not deliver value for money. Yet they extract millions - tens of billions - of pounds out of their clients for fees and transaction costs.

During their business success, which is largely based around accumulating more assets to manage, they have acquired substantial economic and social power.

They do not want it. They are uneasy by it. It is an unintended by-product of commercial success. They would rather not have responsibilities for pay, remuneration or anything like that. Yet fund managers can importantly influence the attitude of companies to the payment of tax, how much they spend on R\&D, whether they are offshore or onshore, and whether they in-source or outsource. These pressures apply to these fund managers, who do not really have an interest in the outcome and do not have much competency in responding to it. Nevertheless, they have this huge power.

Professor, in my opinion most people who have power have gone out intentionally to achieve power. They have gone into politics, or into the upper echelons of universities to be vicechancellors rather than sticking to their academic calling.

Fund managers have this power entirely coincidentally. They would rather not have it, but they have the power to make or break.

I will give you an example. When I was young, one of the great British companies was the glassmaker Pilkington. Pilkington was a world leader in float glass technology. It was based in St Helens in Lancashire.

It was acquired about 10 years ago by Nippon Glass. Since then nearly all the technology and production has moved from St Helens, which is now increasingly a shell community, to Japan. Interestingly, the chairman of Pilkington at that time subsequently became chairman of Arm Holdings, which was Britain's leading publicly quoted technology company. It was taken over by a Japanese company 2 years ago called SoftBank. Last year, Softbank transferred all the intellectual propriety patents of ARM Holdings out of the UK into a company in China.

So far as the investors were concerned, it was a bid which came just after the Brexit referendum. It was at a $30 \%$ or $40 \%$ premium and the Prime Minister and the Chancellor of the Exchequer said, "We welcome this bid. It is evidence that Britain is open for business". No! It is evidence that we have the mentality that our major companies are part of a garage sale.

The President: I have one more question from online. This is from Nick Spencer. This is about sustainable investments and climate risks. "Is that sort of thinking a step in the right direction? Is it insufficiently applied?"

Lord Myners: It should be at the heart of investment decision-making. If you invest in a company which is doing morally suspect things, then you need to be cautious about valuation. We do have 
the issue about externalities, which is where a company pursues what is in its own best interests but there are consequences for broader society.

I worry about that because we are consuming our world very rapidly. We are certainly not renewing the things that we are consuming. Any good investor should take into consideration environmental, social and governance (ESG) issues.

There is a case for giving ESG mandates, and it is not a necessary consequence that they produce lower returns. In fact, I would argue that an ESG approach may produce better returns. I am involved with a firm that manages ESG funds. I am involved with another firm. This is a fund to show you that you can do what I say. I am a general partner in a fund of $€ 13$ billion that has only 12 investments. That is high conviction. We have no under-weightings. We sit on the boards of $75 \%$ of the companies in which we are invested. We have ESG as a primary screen. So, it can be done, and the two can be linked together.

Mr J. E. Gill, F.F.A.: Do you think that regulators, which are regularly blamed for short-term problems, are likely to have an appetite for the increase in short-term volatility that a long-term focus would bring?

Lord Myners: I have tried to read widely about this. I found myself getting into neurological studies and the book by the two American academics who got a Nobel Prize 3 or 4 years ago on heuristics. They delved into decision-making in the short term and the long term and how people could respond differently if a problem was posed in one way rather than another.

But there was an inclination to over-discount the longer term and to take the cake and eat it now rather than put it away for a while. The first stage of being able to become comfortable with a longer-term approach must be to accept the rigour of some of the arguments that are advanced to suggest that we are overly short term.

As I said, I believe that that short-term attitude is pervasive at every point in the investment chain. It is not just the problem with the fund managers. It is not just the problem with the companies. The reason why we have 3-year long-term incentive plans for chief executives is because 3-years is better for the executives than 4- or 5-year plans - or, at least, that is the way that they think it is.

We all must become more comfortable with what you are referring to.

The President: I have two questions from Twitter. One is, "Is the conclusion, then, that private equity is the solution?"

The second question is from Amy at the University of Exeter, who said, "With so many graduates going straight into fund management, what is the responsibility of universities to instil long-term thinking?"

Lord Myners: Let us deal with the second one first. Universities do have a duty to address some of these issues. It is not just in finance. I would hope in the business school, under Prof David Allen at Exeter, that there is plenty of discussion about the longer term.

You are right that many graduates are going into finance, investment banking and investment management. The good news is that graduate career choices are generally a good indicator of an industry which is going to go into decline. Certainly, if I were young now, I would not be going into financial services with the expectation that I would be anywhere as well-rewarded as I have been over the past 30 years.

In answer to the first question, about 20 years ago one of our fund managers at Gartmore said, "I should like to introduce you to a man who is coming to the office in a few days' time, but I want to give you some briefing notes in advance." The visitor was Henry Kravitz of KKR, the Wall Street private equity giant. 
Brian O'Neill, a Scot, said to me, "You will look at their performance numbers and be very impressed, Paul." But, in fact, if you had taken a portfolio of American equities and simply leveraged them, how much leverage would you have had to apply to the portfolio to get the same return? He said that the outcome was $9 \%$.

Compared with the embedded leverage within a private equity fund in the companies within the fund, that is lower risk, but anybody who went to a board of trustees and said, "Do not invest in private equities, just leverage your equities" would be laughed out of town. But that is the discussion that trustees should at least have to understand the issues better.

Private equity is expensive. It lacks transparency. But it is benefiting from one of the effects that I have described, which is the general wish of bright managers not be in the public equity arena.

The problem for private equity is it is an interim holding period. Private equity has a flaw in its business model in that it must sell on.

Good private equity firms, like CVC and Carlisle, are now launching funds with a much longer duration. They are talking about keeping their investments for 20 years or so. Private equity is a sensible place to invest.

I have to say that hedge funds have been very disappointing over the past 10 years. That is one asset class that I will be looking at with great caution. They may manage too much money. They may have become so pressurised by consultants and trustees to have formal processes that the spark that was there with great fund management, that intuition, decisions made from the heart rather than from the head, has been smothered out of what they do. I am cautious about hedge funds. Finally, infrastructure is a great asset for a pension fund and a long-term scheme. The problem there is that fund managers have not been willing to take as much risk and they have expected the Government to take most of the risk. So, the returns have not been as high as they should be.

Despite institutions saying "We are ready to put lots of money into highways, airports, etc.", you can bet that little money will go into HS2 or the Third Runway or any other major project from institutional investors, except in the lowest risk tranche, which is guaranteed by the Government.

The President: Lord Myners, much of what you touched on in your lecture is close to the heart of the actuarial profession - long-termism and understanding value, and economic sustainability. Your lecture was really apt and appropriate and the following discussion interesting and lively.

Cite this article: Autumn Lecture 2018, presented by Baron Myners of Truro: in investment how do we define long term? Abstract of the Edinburgh Discussion British Actuarial Journal, 24. https://doi.org/10.1017/S135732171900014X 